\title{
Central African Republic
}

National Cancer Institute

\section{Source}

National Cancer Institute. Central African Republic. NCI Thesaurus. Code C16409.

A country in central Africa, north of Democratic Republic of the Congo, between

Cameroon and South Sudan. 